\title{
The Impact of COVID-19 in Sub-Saharan Africa Food Security and Human Development
}

\author{
José Guina, Jorge Ferrão, Victoria Bell, and Tito Fernandes
}

\section{ABSTRACT}

Poverty, malnutrition, food insecurity, and hunger are social determinants of health, well-being, and when associated with other resource-related hardships (e.g., housing instability, energy insecurity) are serious and costly constraints to human development. Sub-Saharan Africa is home to the world's poorest countries and most family farmers do not have access to markets, important determinant for economic development. African traditional eating has been related to sustainability and positive health outcomes although the scenario is shifting to modern occidental foods. Food fortification with micronutrients may not be the right solution when there is no data on basic dietary intake. Further to the long existing housing, energy and water crisis, family farmers living at subsistence level, their livelihoods and communities, are now facing deeper worries and sufferings on food supplies. Sub-Saharan Africa was faced with a myriad of hurdles, where climate change was considered the greatest challenge, until COVID-19. Urgent priority call for high-impact initiatives and recommendations that are feasible in each of the national contexts. Success will only be achieved through strong public investment on health sectors, agricultural extension services, irrigation, and rural infrastructures.

Keywords: food security; Sub-Saharan; COVID-19; poverty; development.
Submitted : March 20, 2021

Published : April 10, 2021

ISSN: $2684-1827$

DOI: 10.24018 /ejfood.2021.3.2.267

José Guina

ISEUNA, Polytechnic University, N13, Nampula, Mozambique.

(e-mail: Jose.guina@gmail.com)

Jorge Ferrão

Vice-Chancellor's Office, Universidade Pedagógica, Rua Comandante Augusto Cardoso, Maputo, Mozambique.

(e-mail: reitoria@up.ac.mz)

Victoria Bell

Faculty of Pharmacy, Coimbra University, Portugal.

(e-mail: victoriabell@ff.uc.pt)

Tito Fernandes*

CIISA, Faculty of Veterinary Medicine,

University of Lisbon, Portugal.

(e-mail: profcattitofernandes@gmail.com)

*Corresponding Author

\section{INTRODUCTION}

Poverty, malnutrition, food insecurity, and hunger are as old as time, likely to prevail in the future and never end, namely in Africa. These situations co-exist with a world full of conflicts, wars, climate changes, corruption, leaders' ineptitude, and human greediness.

SARS-CoV-2 poses an enormous extra challenge to development aspirations. The coronavirus disease, COVID19 , seriously affected the global economy with serious other consequences, assuming further difficulties in achieving the Sustainable Development Goals [1]. Despite many efforts from a vast number of national and international organisations, including the United Nations (WHO, FAO, WFP, IFAD, UNICEF), the journey towards achieving the 2030 Agenda for Sustainable Development remains critical [2].

In the past decades, neoliberal globalizers induced contemporary global food crisis, including market distortions, produced by large-scale government subsidies in developed countries while preaching free trade. Low income countries rely heavily on trade of international primary commodities while policymakers and business communities rely on the US dollar, and not encourage local currencies [3].

Sub-Saharan Africa (SSA) is home to the world's poorest countries and most family farmers do not have access to markets, important determinant for economic development, and safe, sufficient and adequate food, while this poor trade facilitation constitutes a significant driver of food insecurity in Africa [4].

African traditional eating has been related to sustainability and positive health outcomes, while presently there is a shift to modern occidental foods rich in saturated fats, sugar, and sweeteners [5].

Even before COVID-19 the soaring food prices of basic staples generated resentment, social fragmentation, poor health, and economic recession. It was considered that unless the world reversed decades of neglect of small-scale farming in Africa and transformed the way food is grown, harvested, and sold, the current crisis could become permanent. With the present pandemic the future situation is alarmingly unknown and unpredictable, and rather than rushing back to normal, lessons must be learned from the past and try to mitigate future risks. 
Meanwhile, malnutrition and chronic hunger with concurrent highest rates of obesity is one of the greatest paradoxes of our time in Africa. Many international organisations and national programmes and legislation suggest food fortification with micronutrient to suppress deficiencies, however, it does not consider that it is still undetermined the national data on basic dietary intake [6]. However, the aptitude to assemble dependable and pertinent Sub-Saharan data to truly evaluate the dimension and severity of food crisis is still lacking.

And the turmoil set in motion by the COVID-19 pandemic disrupts food supplies and is driving smallholders, families and communities into deeper worries and sufferings. The most vulnerable people, namely women and their offspring, working in informal agricultural and other family sectors, have experienced catastrophic repercussions on their livelihoods and food security.

The present article describes some food security events, the impact from COVID-19, and considers briefly some options for development strategies although not including the complex factors such as land and agriculture, healthcare, education, transport, labour, communications, research, gender policies and other mainstream strategies conditioning food production and availability.

\section{THE STRUGGLE FOR FOOD}

From being self-sufficient in the 1960's, Africa has become a net importer of cereals due to population growth. However, contrary to common opinion, agricultural production in Africa has consistently increased where stock's yield has been increased and accomplished by cultivating more land area but with modest development in production factors (labour, capital, land) [7].

The unsteady history of the struggle against hunger, namely in rural areas, is as old as humankind whose populations had to adapt over and over to changing environmental conditions, epidemics, and many other misfortunes such as the new pandemic. Despite all, the world produces enough food to feed 10 billion people, poverty and hunger prevail because of economics, not scarcity [4].

Africa, with its considerable and underexploited agricultural potential, showed some reductions in hunger and poverty, and increases in productivity. This includes countries such as Ghana, Togo, Zambia, Burundi, Burkina Faso, Mali, Niger, Congo, Senegal, Ethiopia, and Malawi.

Mozambique, for example, with a population of some 30 million, is a food-deficit country with a large rural population (64\% rural and $34 \%$ urban), 67500 children under 5 years being acutely malnourished, of whom 6500 are affected by severe acute malnutrition; some $42.6 \%$ of children under 5 years are stunted (too short for their age). Mozambique, with a dramatic $63.7 \%$ population under poverty, is ranked 180 of 189 countries in the 2019 Human Development Index. The growing food needs in Mozambique driven by climate change, insecurity, displacement, and the socio-economic impact of the COVID-19 pandemic, demands strengthening the national capacity to respond to these issues.

Hunger is more complex than starvation symptoms since it is determined by associated issues such as poverty, economic depreciation, war and conflicts, environmental and climate changes, gender discrimination, weak or corrupt government and health systems, and other factors [8].

Despite the Millennium Development Goals for 2030, and some good examples from Brazil and Ghana, a world without hunger, poverty, discrimination and with no diseases will probably never be achieved since these interconnecting factors cannot be tackled by a single entity.

Concepts of food security have gradually changed in the last forty years while the ethical and human rights dimension of food security is now the centre of attention. The world is still plagued by hunger, with some $10 \%$ of people food insecure, and some countries unable to get enough food on a daily basis. With $20 \%$ of Africans living under the spectre of starvation, namely children, a higher percentage than anywhere else in the world, there is still a long way to go. In fact, with the pandemic the situation has deteriorated.

Actually, food security includes four components: availability, access, utilisation, and political stability [9]. Uncontrolled growth of human populations occurs in the poorer developing regions. Food shortages, unemployment, regional conflicts, and poor political stability contribute to poverty, nutrition insecurity and human development. By 2030, half of all Africans will live in cities and the world is not on track to achieve the immense challenge of Zero Hunger by 2030, goal 2 of the UN sustainable Development Goals.

Some $25 \%$ of the African's population and a third of the Eastern Africa is undernourished while the recent COVID-19 pandemic could result in some more 130 million people into chronic hunger [10].

The burden of hunger, malnutrition in all its forms (wasting, stunting, and underweight) is frequent in SubSaharan Africa, and the concurrence of both under-nutrition and over-nutrition in the same population across the life course probably due to inadequate dietary intake or diseases, is Sub-Saharan Africa's most primary concerns for enhanced human development [11]. It is the largest cause for child health and death, and prevalent risk in the majority of African countries representing a leading threat to socioeconomic development of the continent. After Asia with 381 million people undernourished, Sub-Saharan Africa is the region with the highest prevalence of undernourishment (250 million) questioning the national and regional capacities for eradicating hunger [12].

Africa needs more and better food, locally produced. The imbalance between the traditional and the introduced species impairs the use of indigenous foods that have fed Africans for many centuries and erupts the availability of novel foods. Research on valuable African indigenous foods such as cowpea, yam, and okra, is reduced in favour of soya and other food crops.

There is little health research on diet quality based on what African people actually eat and Africa is increasingly a profit centre for fast food and fizzy beverages from global producers of unhealthy grubs [13].

The physical, mechanical, and mental capacities and disabilities of a population may be dependent on nutrition quality, particularly for young children and women in their childbearing age. Resources will determine the degree to which the three underlying determinants (food, health, and care) are expressed positively or negatively [14]. 
Furthermore, the level of access to information and services for sustaining health, whether preventive and curative health services are less available, and the presence or absence of a healthy environment with pure water, appropriate sanitation, and proper protection all contribute equally to determining the nutritional status of the African people [15]. Sustainable diets in Africa are those with reduced impacts on environment supporting good supply of balanced food, well-being, and healthy lifestyle. Sustainable diets protect and respect the biodiversity and ecosystems, are accepted by local cultures, and have reasonable prices [16].

Social and economic development interacts and connects with biological and cultural dimensions of diversity. African farmers living in their rural homelands and sound ecosystems retain an immense knowledge of biodiversity in food resources. Local food systems of rural communities and their lifestyles have been affected and transformed by modernization [17].

The present global crisis generated by the outbreak of the Covid-19 pandemic raises serious health concerns to African smallholders and exacerbates historic vulnerabilities in many regions, where access to land is important for indigenous peoples' livelihoods and food security. To avert millions of people, namely children, already facing food crisis, from becoming ill to the virus or collapse by the economic impact, all actors and efforts must be mobilized and coordinated along a set of operational and strategic priorities [18].

\section{FOOD AND NUTRITION SECURITY}

For most of the African history, food scarcity has constituted a major threat to survival. Unless the quality of food, related to safety and nutrient composition that Africans eat is addressed, the continent will not be able to address under-nutrition and obesity-related diseases.

The diverse nature of Sub-Saharan African cooking has fantastic elements of different cultures - Arab, Black African, European, and Asian. Knowledge of what it is eaten is essential to dietetics and food science, as well as for biodiversity, agriculture production, and the food industry.

Food security in Sub-Saharan Africa can be considered a result of options for development strategies including land and agriculture, healthcare, education, transport, labour, communications, research, gender policies and other mainstream strategies conditioning food production and availability (Fig. 1).

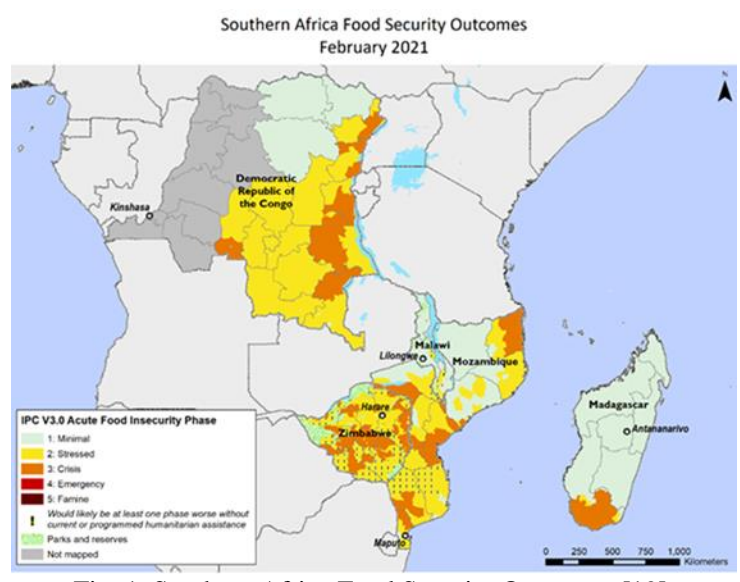

Fig. 1. Southern Africa Food Security Outcomes [19].
Some 90 percent of children in Africa are not fed properly and high food insecurity continues into 2021 [20]. As millions of children in Africa starve, many countries, including Mozambique, have implemented School Feeding Programmes to try and minimize this food insecurity situation. It is usually a basic but nutritious meal of maize flour and beans or soya, which for many of these children, is often their only guaranteed meal of the day while removing hunger as a barrier to learning. This improves the resistance to diseases and has been a success story throughout despite still not covering all schools [21].

The proportion of the population above 60 years of age in sub-Saharan Africa is increasing rapidly and presents many constraints to unprepared healthcare systems now under the strain of the pandemic.

Current food systems in African agriculture and animal production, are unsustainable with no diversification and no adequate integration of indigenous vegetables, being one of the greatest current threats to human health [22], [23].

Africans are moving away from their traditional and nutritive diets and adopting a more Western way of eating, increasing the chances of more chronic diseases that were either rare or unknown [24].

In Africa, food-based dietary guidelines have been established in Benin, Kenya, Namibia, Nigeria, Seychelles, Sierra Leone, and South Africa [25]. Dietary guidelines are rarely evaluated thus their impact remains unknown. Nevertheless, only evidence supporting healthy dietary patterns may provide the foundation for the development of regional dietary guidelines as an educational tool.

In general, Sub-Saharan Africa has more sustainable diets than developed countries and food systems are not simple to achieve. Indeed, nutrition, environment, economic and sociocultural dimensions have been achieved although threatened by invasion of multinational interests [26].

Apparently, a healthy Mediterranean style eating model might seem totally different than traditional African or Asian eating styles, but in reality, these rich cuisines are much more alike than they are different since both are based on components of the traditional dietary patterns. Preference on consumption of health-promoting foods and reduced intake of risky options are intrinsic to good eating habits [27].

The majority of African cuisines has a different starch base (sorghum, millet, maize, teff, cassava, and yams supplying $55-75 \%$ of total dietary energy. Starches are more filling, as they deceive the body into feeling fuller [28]. Usually it is complemented with margarine or oil, supplying an extra source of energy but few essential nutrients where fried onions, garlic and tomatoes make a basic curried sauce [29].

In the poorer regions of Sub-Saharan Africa, micronutrient malnutrition exists, there is undernourishment due to food shortages, and it is likely to become common where diets lack diversity, even in conjunction with sufficient energy. In poor countries, this deficiency is exacerbated by systemic infections and parasitic diseases that reduce nutrient absorption and biological utilization [30].

More than $60 \%$ of the population of Sub-Saharan Africa is smallholder farmers and about $23 \%$ of the GDP (gross domestic product) in the region comes from agriculture. Nevertheless, increasing number of smallholders are abandoning survival strategies and considering agricultural 
production as a real business. Furthermore, agrifood systems are changing, moving away from self-subsistence tendencies and towards commercial agriculture centred on consumer preferences [31].

Food purchases are not yet influenced by consumer health concerns such as managing fat or cholesterol, reducing risk of a disease, defying the aging process, or following doctor's orders, as happens in developed countries. In Africa it is imperative the promotion of foods with a high ratio of micronutrients to energy content, diversifying food sources, balancing food ingredients, moderating intake of alcoholic beverages and of foodstuffs with low quality namely in the elderly and children [32].

\section{FOOD INSECURITY AND POVERTY ON THE RISE}

There is in Africa a food system which has been both successful but also a failure. Despite more food being produced, and relatively cheaper than ever in many circumstances, there has been increased food insecurity and poverty.

Increasing and improving the productivity of smallholders who farm staple crops, poultry, and livestock on very minute patches of land, can help poor people in Africa support the food system, earning more income from what they produce and help meet the demand coming from urban areas for higher-value crops.

There is large scope to help connect poor smallholders to improved production techniques and more profitable markets, bringing them into the value food chain more effectively and enabling them to engage in policy processes.

The dependence on food imports and vulnerability to world price fluctuations, as well as cultural and ethnic influences on feeding practices needs attention. To eradicate food insecurity, there is the need to help poor family holds through a combination of skills in farming, health, education, business, water and sanitation, self-preservation, and social safety nets (Fig. 2).

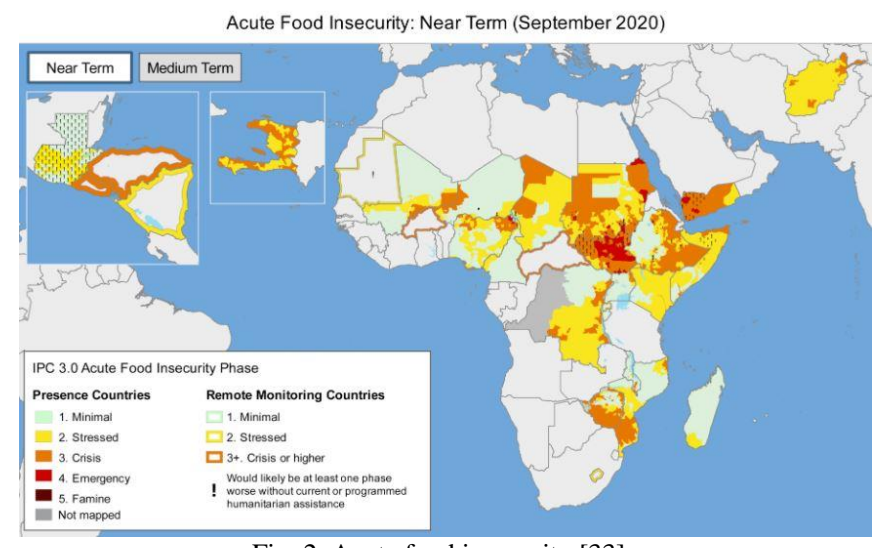

Fig. 2. Acute food insecurity [33].

Food is also a key area in which we interact with our environment. We rely on the environment for $100 \%$ of our food, either from the soil or the oceans and rivers. The main question remains on the interpretation of the nature of the right to food and the "commodification of food" in which it has become constructed as a mere commodity in a global food system losing track of its original purpose: to feed the population. Indeed, food is increasingly used as a means for extracting profit and accumulation [34].

Africa has huge dormant capacity to feed itself and eradicate malnutrition, hunger and food insecurity, and a major player in global food markets. Despite the African Union setting a target to "eliminate hunger and food insecurity by 2025 ", the pandemic hinders this aspiration, besides many other factors.

Food security is a multidimensional concept, and literature is filled with indicators at the individual, household, and macro levels(35). Despite significant accomplishments in the fight against poverty in recent decades, many African countries have the highest poverty rates in the world, with $20 \%$ of Africans living under the spectre of starvation, a higher percentage than anywhere else in the world (Fig. 3). There is still a long way to go.

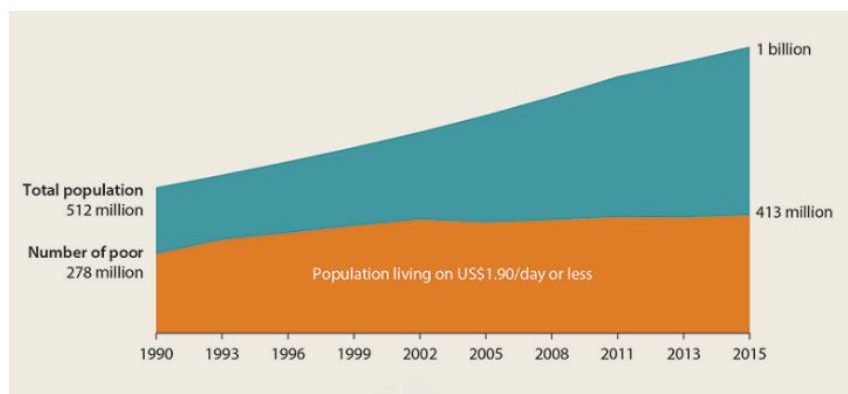

Fig. 3. Due to high population growth during the same period, the number of poor people in Africa has actually increased from 278 million in 1990 to 413 million in 2015 [36].

If circumstances remained the same, the poverty rate was expected to decline to $23 \%$ only by 2030 ; global poverty will become increasingly African, rising from 55\% in 2015 to $90 \%$ in 2030 . With the SARS-CoV-2 pandemic all scenarios have been changed for worst and still unknown.

\section{AGRIBUSINESS AND STAR-UPS}

Tremendous long-term efforts are still needed to achieve the evolution of African agriculture as a driver of economic transfiguration in order to assure the population a more decent life. Since the fate of future African agriculture depends on the fate of family farming systems, the model must be constructed with sustainable intensification around family farmers [37].

The present stage of agrarian education and training in Africa has moved from just increasing its productivity to include agribusiness or agro-industries. However, academic institutions still cannot match the competencies and skills of their graduates with the demand for expertise from agricultural and agri-food companies.

So, African governments still need to make massive financing to warrant adequate implementation of agricultural technical and practical training systems beyond subsistence, building competencies of young people, namely women, to seize the venture opportunities offered by agriculture [38]. It is the responsibility of academic institutions and other capacity-building organisations to develop the type and number of graduates that are able to tackle not only today's challenges. In this singular pandemic actuality, we are also seeing the initiation of a pronounced rearrangement of the 
social and economic order for the path to the next normal following the coronavirus outbreak [39].

One of the mechanisms used to foster small enterprises for more than four decades is "business incubation". These incubators nurture ideas with the hope of building out a business model and/or a company. Business incubators in Sub-Saharan Africa aim at providing infrastructures, entrepreneurship, market linkages, skills, consulting services, credit, subsidies and facilitate cooperation among producers, and expose them to new ICT technologies towards increasing productivity and outreaching markets to flow their produce [40].

With the objective of provision of workspace, mentoring, funding, or training, in Sub-Saharan Africa policymakers and grant-making organisations are nevertheless concerned about the high incubator mortality rates and/or the low success rates of their start-ups. It is known that $90 \%$ of incubators new start-ups, either public or private, fail or die. The observed success stories are positively associated with at least one outcome measure, but few interventions can be positively linked with multiple outcomes.

With the pandemic start-up incubation has truly become a virtual phenomenon on many occasions. As public funds become scarce, incubators are being asked to re-evaluate their business models to help them generate revenues and become self-sustainable organisations. Incubators need to reflect, pivot and re-strategize if they intend to remain relevant in the new post-Covid digital world.

\section{THE IMPACT OF THE PANDEMIC}

There have been significant debates since the emergence of COVID-19 about its potential impact on African and global societies. Presently in 2021 the outlook is even more concerning. The world is facing famines driven by conflicts, aggravated by climate change and yet the COVID-19, driving human misery to a bewildering scale. The pandemic is interlinked with food systems in complex ways, the market proven to be an unreliable governor of food production, distribution, pricing, and consumption.

The susceptibility of food systems to problems related to climate, environment, health disorders and even politics has been experienced long before the COVID-19 crisis and there were some 135 million people worldwide on the brink of starvation. Now this figure may have doubled and the world facing "a hunger pandemic" and "multiple famines of biblical proportions"[41].

The implications of the COVID-19 pandemic for global food security are vast but still unmeasurable and some two billion people face food insecurity at the moderate or severe level [42]. The high degree of uncertainty around the virus and its evolution, and the fact that each country faces specific challenges in addressing the COVID-19 pandemic, determines no common actions and solutions [43].

No clear evidence exists that food itself is a vector for transmission of SARS-CoV-2(44), nevertheless amid the unpredictability posed by COVID-19, the present crisis is causing major and complex disruptions to food supply chains. This chain involves several stages, including agrarian production (livestock and crop production, horticulture, planting, harvesting) or imports, handling, processing, distribution/retail/service, consumption, and disposal. COVID-19 pandemic does not directly affect production but may affect other stages [45].

Food has been treated as a commodity and with the paramount global economic slowdown, triggered by several lockdowns, is affecting food security, nutrition and incomes [46], [47].

The pandemic crisis has triggered some latent and structural criticalities affecting the global agri-food supply, national food systems and the poor smallholder family farmer (Fig. 4).

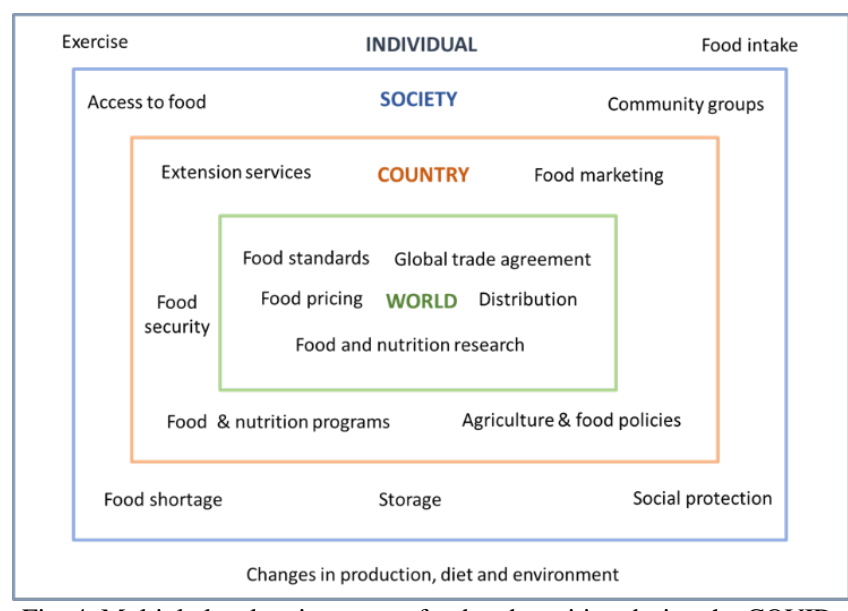

Fig. 4. Multiple level assistance on food and nutrition during the COVID19 pandemic.

For smallholder African family farmers, production is imbalanced, meeting a permanent demand for food for selfconsumption and in some degree for the market [48].

Consumers play a leading role in food supply chain, and as their routine habits are strongly affected by the crisis, the food supply chain is impaired [49]. Strengthening food system resilience is critical for an effective response to the COVID19 pandemic which highlighted the weaknesses of existing food supplies and demands [50].

The opportunities for nutrition interventions in times of Covid-19 are endless [51]. Each country must evaluate the pandemic which is causing many disruptions, breaking food supply chains, loss of revenue and employment, disparity on gender balance, threatening social protection schemes, altering food habitats, and differing food prices in domestic contexts [52]. The disruptions by COVID-19 on the continuity of food flow from producers to consumers, affects all protagonists and mainly food availability leading to some shortages; the UN estimates that around one third of food system livelihoods are at risk due to the pandemic. Increased food production alone is not sufficient to address the present crisis [53].

Support systems to improve productivity at the farm levels will be difficult to implement while consumers shifted their preference for foods with longer shelf life and showed a stronger demand for fresh bread.

\section{CONCLUSIONS}

Despite the large scale of the pandemic, to date there is no report yet that COVID-19 may be transmitted through food consumption. Maintaining the flow of food and commodities 
throughout the supply chain should be ensured with the contribution of all stakeholders in order to improve food security.

As prices raised and most of the population lost their income with the pandemic, it is imperative to warrant immediate access to food for the Sub-Saharan population, particularly for the vulnerable groups, women and children. The top priority under this pandemic circumstance is to call for high-impact initiatives and recommendations that are feasible in each of the national contexts. Success will only be achieved through strong public investment in agricultural extension services, irrigation, and rural infrastructure.

There is the need for identification of positive policy instruments and the commitment, on a collective action, which may at least minimize the negative impacts of Covid19.

\section{CONFLICT OF INTERESTS}

The authors declare that they have no conflict of interest.

\section{REFERENCES}

[1] Filho WL, Azul AM, Wall T, Vasconcelos CRP, Salvia AL, Paço A do, et al. COVID-19: the impact of a global crisis on sustainable development research. Sustain Sci. 2021;16:85-99.

[2] FSIN-Food Security Information Network. Global report on food crises. 2020.

[3] Dada SO. The Bretton Woods Institutions and Economic Development in Africa. Dans: Wariboko N, Falola T, rédacteurs. The Palgrave Handbook of African Social Ethics. Palgrave Macmillan; 2020.

[4] Bonuedi I, Kamasa K, Opoku EEO. Enabling trade across borders and food security in Africa. Food Sec. 2020;12:1121-40.

[5] Fardet A, Rock E. Ultra-Processed Foods and Food System. Sustainability: What Are the Links? Sustainability. 2020;12:6280.

[6] Bell V, Barros AB, Fernandes TH. Food Fortification in Sub Saharan Africa: Science or Business? Dans: Fernandes TH, Ferrão J, Facknath $\mathrm{S}$, rédacteurs. Food and Nutrition Security in Africa. Alcance Ed. Mozambique; 2020.

[7] NEPAD [En ligne]. NEPAD. African agriculture, transformation and outlook; 2013.2 Disponible: https://www.un.org/en/africa/osaa/pdf/pubs/2013africanagricultures.p df.

[8] VonBraun J. Innovations to Overcome the Increasingly Complex Problems of Hunger. 2018. Rapport no 271348.

[9] Devereaux S, Béné C, Hoddinott J. Conceptualising COVID-19's impacts on household food security. Food Sec. 2020;12:769-72.

[10] FAO, IFAD, UNICEF W and W. The State of Food Security and Nutrition in the World 2020: Building climate resilience for food security and nutrition [En ligne]. Rome; 2020. Disponible: https://news.un.org/en/story/2020/07/1068261.

[11] Asongu SA, Odhiambo NM. Environmental degradation and inclusive human development in sub-Saharan Africa. Sustain Dev. 2018;(July).

[12] Dodo MK. Understanding Africa's Food Security Challenges. Dans: Food Security in Africa. 2020.

[13] GBD 2015 Risk Factors Collaborators. Global, regional, and national comparative risk assessment of 79 behavioural, environmental and occupational, and metabolic risks or clusters of risks, 1990-2015: a systematic analysis for the Global Burden of Disease Study 2015. Lancet. 2016;388(10053):1659-724.

[14] Benson T, Shekar M. Trends and Issues in Child Under-nutrition. Dans: Jamison DT, Feachem RG, Makgoba MW, et al., rédacteurs. Disease and Mortality in Sub-Saharan Africa . $2^{\mathrm{e}}$ éd. Washington (DC) : The International Bank for Reconstruction and Development / The World Bank; 2006.

[15] Bouzid M, Cumming O, Hunter PR. What is the impact of water sanitation and hygiene in healthcare facilities on care seeking behaviour and patient satisfaction? A systematic review of the evidence from low-income and middle-income countries. BMJ Glob Heal. 2018;3:e000648.

[16] Fanzo J. Healthy and Sustainable Diets and Food Systems: the Key to Achieving Sustainable Development Goal 2? Food ethics. 2019;4:159-74.
[17] Borelli T, Hunter D, Padulosi S, Amaya N, Meldrum G, de Oliveira Beltrame DM, et al. Local solutions for sustainable food systems: The contribution of orphan crops and wild edible species. Agronomy. 2020;10(2).

[18] Keats EC, Das JK, Salam RA, Lassi ZS, Imdad A, Black RE, et al. Effective interventions to address maternal and child malnutrition: an update of the evidence. Lancet Child Adolesc Heal. 2021;4642(20):30274-1.

[19] FEWS NET [En ligne]. FEWS NET. Southern Africa Acute Food Security Classification (February - September 2021); 2021. Disponible: https://fews.net/fews-data/333.

[20] WFP. Global Operational Response Plan 2021 [En ligne]. 2021. Disponible:

https://reliefweb.int/sites/reliefweb.int/files/resources/WFP0000123959.pdf.

[21] Chabite IT, Garrine C, Ferrão LJ, Fernandes TH. Malnutrition and school feeding programmes. J Nutr Heal Food Eng. 2018;8(5):340-4.

[22] OurWorldInData.org [En ligne]. Ritchie H. Environmental impacts of food production; 2020. Disponible: https://ourworldindata.org/environmental-impacts-of-food.

[23] Molina PB, D’Alessandro C, Dekeyser K, Marson M. Sustainable food systems through diversification and indigenous vegetables [En ligne]. 2020. Disponible: https://ecdpm.org/wp-content/uploads/SustainableFood-Systems-Through-Diversification-Indigenous-VegetablesAnalysis-Arusha-Area-ECDPM-Report-March-2020.pdf.

[24] Vorster HH, Kruger A, Margetts BM. The nutrition transition in Africa: can it be steered into a more positive direction? Nutrients. 2011;3(4):429-41.

[25] [En $\quad$ ligne]. FAO; $2018 . \quad$ Disponible: http://www.fao.org/nutrition/education/food-dietaryguidelines/regions/africa/en/.

[26] Tapsell LC, Neale EP, Satija A, Hu FB. Foods, Nutrients, and Dietary Patterns: Interconnections and Implications for Dietary Guidelines. Adv Nutr. 2016;7(3):445-4454.

[27] Cena N, Calder PC. Defining a Healthy Diet: Evidence for the Role of Contemporary Dietary Patterns in Health and Disease. Nutrients. 2020;12(2):334.

[28] Vorster HH. Make starchy foods part of most meals: a food-based dietary guideline for South Africa. S Afr J Clin Nutr. 2013;26(3):S28-35.

[29] Chastenet M, Chouin G, Lima D, et al. Towards a history of foodways in Africa before the 20th century. Afriques [En ligne]. 2014;5. Disponible: http://journals.openedition.org/afriques/1857.

[30] Walson JL, Berkley JA. The impact of malnutrition on childhood infections. Curr Opin Infect Dis. 2018;31(3):231-6.

[31] Sakho-Jimbira S, Hathie I. Southern Voice. The future of agriculture in Sub-Saharan Africa [En ligne]. 2020. Disponible: https://www.ifad.org/documents/38714170/42030191/future_agricult ure_sahara_e.pdf/1cb6b896-b9c1-0bb8-87b8-83df3153d0af.

[32] Zandile J, Mchiza ZJ, Steyn NP, Hill J, et al. A Review of Dietary Surveys in the Adult South African Population from 2000 to 2015. Nutrients. 2015;7:8227-50.

[33] FEWS NET [En ligne]. FEWS NET. Acute Food Insecuruity; 2020. Disponible: https://fews.net/fews-data/333.

[34] Zerbe N. Food as a Commodity. Dans: Vivero-Pol JL, Ferrando T, Schutter O de, Mattei U, rédacteurs. Routledge Handbook of Food as a Commons. London : Routledge; 2019.

[35] Caccavale OM, Giuffrida V. The Proteus composite index: Towards a better metric for global food security. World Dev. 2020;126(C).

[36] Washinton, DC:World Bank [En ligne]. Beegle K, Christiaensen L. Accelerating Poverty Reduction in Africa; 2019. Disponible: https://openknowledge.worldbank.org/handle/10986/32354 License: CC BY 3.0 IGO.

[37] Carlisle L, Wit MM de, DeLonge SS. Transitioning to Sustainable Agriculture Requires Growing and Sustaining an Ecologically Skilled Workforce. Front Sustain Food Syst. 2019; November.

[38] Kirui OK, Kozicka M. Vocational Education and Training for Farmers and Other Actors in the Agri-Food Value Chain in Africa [En ligne]. Bonn; 2018. Rapport no $164 . \quad$ Disponible: https://www.econstor.eu/handle/10419/187470.

[39] Hassan NA. University business incubators as a tool for accelerating entrepreneurship: theoretical perspective. Rev Econ Polit Sci. 2020; May.

[40] David-West O, Umukoro IO, Onuoha RO. Platforms in Sub-Saharan Africa: startup models and the role of business incubation. J Intellect Cap. 2018;19(3):581-616.

[41] WFP. COVID-19: Potential impact on the world's poorest people: A WFP analysis of the economic and food security implications of the pandemic [En ligne]. 2020. Disponible: https://docs.wfp.org/api/documents/WFP- 
0000114205/download/?_ga=2.230705567.1649880489.1616149166389751477.1616149166.

[42] World Food Programme Insight, 22 April 2020 [En ligne]. Khorsandi P. WFP chief warns of 'hunger pandemic' as Global Food Crises Report launched; 2020. Disponible: https://insight.wfp.org/wfp-chiefwarns-of-hunger-pandemic-as-global-food-crises-reportlaunched3 ee3edb38e47.

[43] Naja F, Hamadeh R. Nutrition amid the COVID-19 pandemic: a multilevel framework for action. action Eur J Clin Nutr. 2020;74:1117-21.

[44] Rizou M, Galanakis IM, Ajdawoud TMS, et al. Safety of foods, food supply chain and environment within the COVID-19 pandemic. Trends Food Sci Technol. 2020;102:293-9.

[45] Stephens EC, Martin G, Wijk M, et al. Editorial: impacts of COVID19 on agricultural and food systems worldwide and on progress to the sustainable development goals. Agric Syst. 2020;183:102873.

[46] The High Level Panel of Experts on Food Security and Nutrition. Interim Issues Paper on the Impact of COVID-19 on Food Security and Nutrition (FSN) [En ligne]. Rome; 2020. Disponible: http://www.fao.org/fileadmin/templates/cfs/Docs1920/Chair/HLPE_E nglish.pdf.

[47] The High Level Panel of Experts on Food Security and Nutrition. Food Security and Nutrition: Building a Global Narrative towards 2030. Report $15 \quad$ [En ligne]. Rome; 2020. Disponible: http://www.fao.org/3/ca9731en/ca9731en.pdf.

[48] Lugo-Morin. Global Food Security in a Pandemic: The Case of the New Coronavirus (COVID-19). World 2020. 2020;1:171-90.

[49] Worstell J. Ecological Resilience of Food Systems in Response to the COVID-19 Crisis. J Agric Food Syst Community Dev. 2020;9:23-30.

[50] Tarra S, Mazzocchi G, Marino D. Food System Resilience during COVID-19 Pandemic: The Case of Roman Solidarity Purchasing Groups. Agriculture. 2021;11(156).

[51] Muscogiuri G, Barrea L, Savastano S. Nutritional recommendations for CoVID-19 quarantine. Eur J Clin Nutr. 2020;74:850-1.

[52] Aday S, Aday MS. Impact of COVID-19 on the food supply chain. Food Qual Saf. 2020;4(4):167-80.

[53] United Nations (UN). The Impact of COVID-19 on Food Security and $\begin{array}{llll}\text { Nutrition } & \text { [En ligne]. }\end{array}$ https://reliefweb.int/sites/reliefweb.int/files/resources/sg_policy_brief _on_covid_impact_on_food_security.pdf. 